\title{
Genotyping and morphometric analysis of Kazakhstani grapevine cultivars versus Asian and European cultivars
}

\author{
A.S. Pozharskiy ${ }^{1}$, K.P. Aubakirova ${ }^{1,2}$, D.A. Gritsenko ${ }^{1,2,3}$, N.I. Tlevlesov ${ }^{1}$, \\ N.Zh. Karimov ${ }^{1}$, N.N. Galiakparov ${ }^{2}$ and N.A. Ryabushkina ${ }^{2}$ \\ ${ }^{1}$ Kazakh Scientific Research Institute of Animal Husbandry and Forage \\ Production, Kazakhstan \\ ${ }^{2}$ Institute of Plant Biology and Biotechnology, Kazakhstan \\ ${ }^{3}$ Al-Farabi Kazakh National University, Kazakhstan
}

Corresponding author: D.A. Gritsenko

E-mail: d.kopytina@gmail.com

Genet. Mol. Res. 19 (1): gmr18482

Received August 30, 2019

Accepted January 11, 2020

Published February 29, 2020

DOI http://dx.doi.org/10.4238/gmr18482

\begin{abstract}
Grapes are an important fruit crop in Kazakhstan. Modern viticulture requires inclusion of traditional morphological and agronomical methods in the development and sustaining of grapevine culture as well as molecular approaches. We used molecular markers and leaf shape analysis to characterize grapevine cultivars developed in Kazakhstan compared with European and Asian varieties. A set of 17 landmarks describing grapevine leaf shape were analyzed using generalized procruste and principal component analyses in order to evaluate shape variation among cultivars. Mean leaf shapes were obtained for 94 cultivars. Outer tip pattern had the most impact on leaf shape variation. Principal component analysis revealed the complex nature of grapevine leaf shape variation and demonstrated the differential impact of leaf landmarks on shape variation. The standard set of six simple sequence repeat markers used for molecular genotyping was sufficient to differentiate each of the cultivars by a distinct allelic profile. Kazakh grapevine cultivars were found to be an admixture of European and Asian varieties. However, for some cultivars, there was no confirmation of identity with respect to pedigree either by bibliography or comparison with the Vitis International Variety Catalogue. Also, 11 markers for resistanceassociated alleles in corresponding loci (RUN1, REN1, REN3, Rpv3, Rpv10, and $R p v 12$ ) were applied to characterize Kazakhstan and some parent cultivars with different levels of resistance to mildew pathogens.
\end{abstract}

Key words: Grapevines; Kazakhstan; Simple sequence repeat (SSR); Mildew resistance; Oidium; Leaf shape 


\section{INTRODUCTION}

Grapevines are one of the most important fruit plants in the world, especially in Kazakhstan. The fall of the USSR caused a period of economic instability in Kazakhstan, significantly damaging its grapevine culture. Government programs and regulations aimed at restoring viticulture in Kazakhstan include addition of new and replacement of old vineyards. Viticulture recovery depends on evaluation of available cultivated varieties as well as standardization and certification of Kazakhstan selected cultivars, which includes assessment of genetic diversity and common pathogen resistance. A lack of correct and precise cultivar information can be a significant problem for long-term viticulture development.

The morphological characterization of Vitis taxa (ampelography) that has been used for grapevine characterization for centuries is still a useful approach (Chitwood et al., 2014). The International Organization of Vine and Wine (OIV) descriptor uses a series of morphological characteristics of grapevine plants, including leaf parameters, as diagnostic criteria for cultivar description and identification. Despite the influence of environmental conditions on leaves (Bodor et al., 2013; Sack and Scoffoni, 2013) leaf shape is mostly dictated by genetics, whereas parameters related to size are influenced by both internal and external factors (Welter et al., 2007; Alba et al., 2014; Chitwood et al., 2014). Thus, a promising approach to grapevine characterization is based on methods that allow separation of size and shape components (Viscosi and Cardini, 2011). Along with ampelography description of grapevine varieties, data based on molecular markers have increasing use in grapevine cultivar certification (Aradhya et al., 2003; Welter et al., 2007; Hvarleva et al., 2009; Emanuelli et al., 2013; Riaz et al., 2013; Marrano et al., 2015). Molecular characterization of grape germplasms has shown that their genetic diversity is strongly influenced by cultivar putative origin and distribution of diverse underlying genetic resources (Bacilieri et al., 2013, Emanuelli et al., 2013). Among all molecular markers, simple sequence repeats (SSR) are a reliable, highly reproducible, and relatively cheap way to classify grapevine varieties and resolution of ambiguous cultivar assignment (Sefc et al., 2009; Pokhriyal et al., 2012). A set of six SSR markers was proposed as a standard by the OIV and recognized by the international community (This et al., 2004). These markers were included in the second edition of the OIV descriptor list for grape varieties and Vitis species as OIV 801806. Previous studies have also demonstrated that some morphological parameters can be sufficient for correct cultivar discrimination in combination with molecular methods in ambiguous cases (Alba et al., 2014; Alba et al., 2015). An important problem in worldwide viticulture is the susceptibility of grapevines to pathogens, leading to severe economic damage, including yield loss and indirect negative effects of pesticides. Among the most destructive diseases of grapevines are powdery mildew (PM) caused by the ascomycete Erysiphe necator [syn. Uncinula necator] and downy mildew (DM) caused by the oomycete Plasmopara viticola (Gessler et al., 2011; Armijo et al., 2016). International efforts are being made to identify genetic sources of resistance to these diseases as well as heritability and stability of this resistance in the field in order to introduce these sources into cultivars by crossbreeding. For instance, the PM resistance locus $R U N 1$ has been introduced by pseudo-backcross into the Vitis vinifera $(2 \mathrm{n}=38)$ genome from the wild North American species Muscadinia rotundifolia [syn. V. rotundifolia; 2n $=40$ ] (Merdinoglu et al., 2003; Barker et al., 2005). In certain accessions of $V$. vinifera from Central Asia, including Uzbekistan cultivars Kishmish vatkana and Dzhandzhal kara, a major Rgene in the REN1 locus was discovered. Though less effective than RUN1, it can still significantly restrict $\mathrm{PM}$ growth and sporulation relative to susceptible $V$. vinifera cultivars (Hoffmann et al., 2008; Coleman et al., 2009; Agurto et al., 2017). SSR markers linked with the resistant RENI allele (143 bp) allowed identification of 10 new mildew resistant genotypes, 
eight of which are $V$. vinifera cultivars (three related to Kishmish vatkana and Karadzhandal) and two are $V$. vinifera subsp. sylvestris (Riaz et al., 2013). The REN3 locus was discovered in the cultivar Regent, a full sibling of Villard blanc, the resistant ancestors of which were $V$. aestivalis, $V$. berlandieri, $V$. cinerea, $V$. lincecumii, and $V$. rupestris (Eibach and Töpfer, 2003; Welter et al., 2007). In cultivar Bianca, which has common wild ancestors with Regent through Villard blanc, the Rpv3 locus has been detected as a major quantitative trait locus responsible for DM resistance (Bellin et al., 2009). Wild $V$. amurensis is the source of DM resistance locus Rpv10 (LG 09), which was introgressed into grapevine varieties of Western Europe (Schwander et al., 2011). A quantitative trait locus analysis revealed the dominant gene Rpv12 for DM resistance was inherited from $V$. amurensis independent of other resistance genes (Venuti et al., 2013). Researchers have also demonstrated the additive effect of Rpv12 and Rpv3 in conferring resistance to strains that were virulent to $R p v 3$ plants.

Kazakhstan is not a native region for grapes, and only the Kuldzhinskyi cultivar is indigenous. Most common cultivars in vineyards of Kazakhstan are European or Caucasian (Rkatsiteli, Saperavi, Cabernet franc, Cabernet sauvignon, etc.) and Central Asian (Taifi rozovyi, Kuldzhinskyi, Akhalili, Khusaine belyi). Local grapevine cultivars were bred from these Eurasian cultivars (Nurmuratuly et al., 2012).

We examined phylometric and molecular markers of grapevine characteristics from cultivars developed in Kazakhstan and compared them with a number of European and Central Asian cultivars. Generalized procrustes analysis (GPA) with principal component analysis (PCA) were performed to evaluate shape variation, and the standard set of six SSR markers (OIV 801-806) was used for molecular genotyping. Furthermore, 11 markers for loci RUN1, REN1, REN3, Rpv3, Rpv10, and Rpv12 were applied to characterize Kazakhstan cultivars as a prospective source of genotypes resistant to mildew pathogens.

\section{MATERIAL AND METHODS}

\section{Plant material collection}

All investigated cultivars were developed by the Institute of Horticulture and Viticulture (Almaty region, Kazakhstan) and collected in the Pomological Garden of the Institute. Information about local cultivars provided by the Institute of Horticulture and Viticulture is shown in Table Supplementary 1. Two sets of material were collected depending on their availability. For morphometric analysis, mature leaves were collected from the middle third of several shoots and preserved in an herbarium. For molecular analysis, leaves up to $25 \mathrm{~mm}$ in width were stored at $-80^{\circ} \mathrm{C}$.

\section{Morphometric analysis}

Mature leaves were digitized by scanning at 150 dpi and saved as bitmap files. Coordinates of 17 key landmarks of leaves (Figure 1) were obtained using the ImageJ software. GPA was performed using the R package Geomorph (Adams et al., 2017). For visualization of results, the ggplot2 package was used (Wickham, 2009).

\section{Microsatellite analysis}

Analysis was conducted in laboratory facilities of the Institute of Plant Biology and Biotechnology (Almaty, Kazakhstan). Genomic DNA was extracted according to a previous 
protocol (Doyle and Doyle, 1990), with minor modifications. Loci were amplified via PCR using primer sets for six standard loci markers (VVS2, VVMD5, VVMD7, VVMD27, VrZAG62, and VrZAG79) combined with three universal unspecific oligonucleotides (D8S1132, D12S1090, and DYS437) that were labeled with fluorescent dyes (VIC, NED, and FAM, respectively) used as "tails" (Table 1). PCR was conducted in a $20 \mu \mathrm{L}$ total volume, containing $20 \mathrm{ng}$ of genomic DNA, $2.5 \mathrm{mM} \mathrm{MgCl} 2,0.2 \mathrm{mM}$ of each dNTP, $0.2 \mathrm{mM}$ forward primer, $0.2 \mathrm{mM}$ labeled primer, $0.1 \mathrm{mM}$ primer with a "tail," and $1 \mathrm{U}$ of Taq-polymerase (Thermo Scientific) in conventional $1 \times$ ammonium TaqBuffer. The cycling profile was as follows: $94^{\circ} \mathrm{C}$ for $2 \mathrm{~min}$ followed by 7 cycles at $94^{\circ} \mathrm{C}$ for $1 \mathrm{~min}, 60^{\circ} \mathrm{C}$ for $2 \mathrm{~min}, 72^{\circ} \mathrm{C}$ for $2 \mathrm{~min}$; 20 cycles at $94^{\circ} \mathrm{C}$ for $1 \mathrm{~min}, 54^{\circ} \mathrm{C}$ for $2 \mathrm{~min}, 72^{\circ} \mathrm{C}$ for $2 \mathrm{~min}$; and final extension at $72^{\circ} \mathrm{C}$ for 10 min. Aliquots of the amplification products were checked by $1 \%$ agarose gel electrophoresis. The amplification products of all six markers per sample were combined and mixed with formamide and the size standard LIZ (Size Standard 500 LIZ, Applied Biosystems) so that in a $10 \mu \mathrm{L}$ total volume, PCR products labeled by VIC, NED, and FAM were diluted 540-, 120-, and 360 -fold, respectively. Samples were run on a 310 Genetic Analyzer (Applied Biosystems). Data were processed by GeneMapper Software 4.0 (Applied Biosystems) and alleles defined by their size (in bp). Analysis of genotypic data included distance-based unweighted pair-group method with arithmetic mean (UPGMA) and Bayesian clustering. Statistical summary of genotyping results was obtained using GenAlex 6.5 for Excel. Bayesian clustering was performed using STRUCTURE 2.3.4 as follows: 10 values of $\mathrm{K}$ were run 10 times with 100,000 burn-in and 100,000 analyzing iterations, using an allelic admixture model with correlated alleles. Ten independent runs were aligned, and mean cluster configuration was calculated using CLUMPP [greedy algorithm, 100 random permutations tested]. Results were visualized using Distruct 1.1 (Rosenberg, 2003). UPGMA clustering based on Bruvo genetic distances was performed using $\mathrm{R}$ packages poppr and ape.

Table 1. Sequences of primers used for SSR genotyping and resistance-associated marker amplification in Vitis vinifera.

\begin{tabular}{|c|c|c|}
\hline Locus & Forward primer & Reverse primer \\
\hline \multicolumn{3}{|c|}{ SSR markers; "tails" are designated by codes of corresponding fluorescently labeled primers } \\
\hline VVS2 & 5'-AAATTCAAAATTCTAATTCAACTGG-3' & 5'-D8S1132-CAGCCCGTAAATGTATCCATC-3' \\
\hline VVMD5 & 5'-TATACCAAAAATCATATTCCTAAA-3' & 5'-D8S1132-CTAGAGCTACGCCAATCCAA-3' \\
\hline VVMD7 & 5'-AGAGTTGCGGAGAACAGGAT-3' & 5'-DYS437-CGAACCTTCACACGCTTGAT-3' \\
\hline VVMD27 & 5'-GTACCAGATCTGAATACATCCGTAAGT-3' & 5'-D8S1132-ACGGGTATAGAGCAAACGGTGT-3' \\
\hline VrZAG62 & 5'-GGTGAAATGGGCACCGAACACACGC-3' & 5'-D12S1090-CCATGTCTCTCCTCAGCTTCTCAGC-3' \\
\hline VrZAG79 & 5'-AGATTGTGGAGGAGGGAACAAACCG-3' & 5'-D12S1090-TGCCCCCATTTTCAAACTCCCTTCC-3' \\
\hline \multicolumn{3}{|c|}{ Resistance-associated markers for oidium and mildew } \\
\hline GF12-22 & 5'-GCCAAGTTAGACGAAGTGCAA-3' & 5'-ACGGTTTCCTTTTCAACCAGT-3' \\
\hline GF12-07 & 5'-AGGGTTTGTATTGTTTGGGAGA-3' & 5'-GTGGAAGTGTGAAGTAACGTGG-3' \\
\hline GF15-28 & 5'-TGCACACAATCACAGAGAGAGA-3' & 5'-TGCGGTTAATTTTGACTCCTTC-3' \\
\hline GF18-08 & 5'-GACAATAGCGAGAGAGAATGGG-3' & 5'-AGTTGGCTAAAACCCTAGAGGC-3' \\
\hline GF15-30 & 5'-TCACAGTATGCAGTAACCTGGC-3' & 5'-AAAGGGAAAATGAGCAGTTGAG-3' \\
\hline GF09-46 & 5'-GAGAGATTTGAGGGATTGTTGG-3' & 5'-ATCCACGTTTGTAGCCTTTTGT-3' \\
\hline GF09-48 & 5'-TCTGGAAAGCACAGTAGAGAAGTG-3' & 5'-ATGGAAGGAACCAATGCTAAGA-3' \\
\hline GF14-28 & 5'-TTGGTTCATGGTTGATGCTTAC-3' & 5'-ACCACATGCAGACAGGTTAGTG-3' \\
\hline GF18-06 & 5'-GGTCTCCTAGAAAGCCAAGCAA-3' & 5'-TCССТTTTCCCCTTGTTCTCG-3' \\
\hline GF13-13 & 5'-GTGCATCTTCTTCTTCCCAACC-3' & 5'-GCATTTGTCAAAGTCGTGTACTTC-3' \\
\hline VMC9H4.2 & 5'-GCAGTTGATGCAAAACAACAGT-3' & 5'-CACATCATTCATTGATGAGGCT-3' \\
\hline
\end{tabular}




\section{Amplification of resistance loci to powdery and downy mildew}

Analysis of resistance loci was conducted in the Julius Kühn Institute for Grapevine Breeding (Siebeldingen, Germany). Molecular markers used to characterize loci related to oidium and mildew resistance are presented in Tables 2 and Table Supplementary 2. In the analysis of Kazakhstan varieties, parental varieties were used as a control to confirm the inheritance of sequences cosegregated with resistance.

Table 2. List of markers used to identify alleles in corresponding loci correlated with resistance to oidium and mildew in Vitis vinifera.

\begin{tabular}{lllllll}
\hline Marker & Pathogen & Locus & LG & Allele, bp & Source of resistance & Reference \\
\hline GF12-22 & oidium & $R U N 1$ & 12 & 187 & VRH & Schwander, 2011, JKI \\
GF12-07 & oidium & $R U N 1$ & 12 & $284 / 288$ & VRH & Zyprian et al., 2016, JKI \\
GF13-13 & oidium & $R E N 1$ & 13 & 214 & 'Kishmish vatkana' & Zhang et al. 2009 \\
VMC9H4.2 & oidium & $R E N 1$ & 13 & 283 & 'Kishmish vatkana' & Hoffmann et al., 2008 \\
GF15-28 & oidium & $R E N 3$ & 15 & 342 & 'Regent' & Schwander, 2011, JKI \\
GF15-30 & oidium & $R E N 3$ & 15 & 452 & 'Regent' & Schwander, 2011, JKI \\
GF18-06 & mildew & $R p v 3$ & 18 & 389 & 'Villard blanc' & Zyprian et al., 2016* \\
GF18-08 & mildew & $R p v 3$ & 18 & 399 & 'Villard blanc' & Zyprian et al., 2016* \\
GF09-46 & mildew & $R p v 10$ & 09 & 416 & 'Solaris' & Schwander et al., 2011 \\
GF09-48 & mildew & $R p v 10$ & 09 & 359 & 'Solaris' & Schwander et al., 2011 \\
GF14-28 & mildew & $R p v 12$ & 14 & 150 & V. amurensis & Schwander, 2011, JKI \\
\hline
\end{tabular}

Notes: VRH - vinivera×rotundifolia hybrid; JKI: Institut für Rebenzüchtung; *- In 'Table of Loci for Traits in Grapevine Relevant for Breeding and Genetics' (last update November 2016)

Multiplex PCR was conducted in $25-\mu \mathrm{L}$ reactions containing $1 \mu \mathrm{L}$ of genomic DNA (1 $\mathrm{ng} / \mu \mathrm{L}), 2.5 \mu \mathrm{L}$ of QIAGEN Master Mix, $0.01 \mu \mathrm{L}(100 \mathrm{pmol} / \mu \mathrm{L})$ of each forward and reverse marker primer, $1.38 \mu \mathrm{L}$ of deionized sterile water. Markers were combined into two groups. In the first group, GF12-22, GF12-07, GF15-28, GF15-30, and GF18-08; in the second group, GF13-13, VMC9H4.2, GF18-06, GF09-46, GF09-48, and GF14-28. The amplification profile was as follows: an initial heat activation step at $95^{\circ} \mathrm{C}$ for $15 \mathrm{~min} ; 30$ cycles at $94^{\circ} \mathrm{C}$ for $30 \mathrm{~s}$, $60^{\circ} \mathrm{C}$ for $1.5 \mathrm{~min}, 72^{\circ} \mathrm{C}$ for $1 \mathrm{~min}$; and final cycle at $72^{\circ} \mathrm{C}$ for $30 \mathrm{~min}$. Amplification products were diluted 2 -fold, and $2 \mu \mathrm{L}$ of the products were mixed with a size standard (Size standard 500 LIZ, Applied Biosystem) according to manufacturer's instructions. Electrophoresis of PCR products was performed on an ABI 3130 DNA analyzer (Applied Biosystems).

\section{RESULTS AND DISCUSSION}

\section{Leaf shape analysis}

Landmark-based methods allow neglect of nonperforming parameters and focus on the shape of the object expressed as a set of points corresponding to its key morphological traits (Viscosi and Cardini, 2011). GPA was performed to test variability of leaf shape among cultivars. Mean shapes for each cultivar were calculated and used for further analysis (Figure Supplementary 1). Three patterns were defined describing veins' first branching points (pattern 1), sinuses (pattern 2), and outer tips (pattern 3) (Figure 1). 


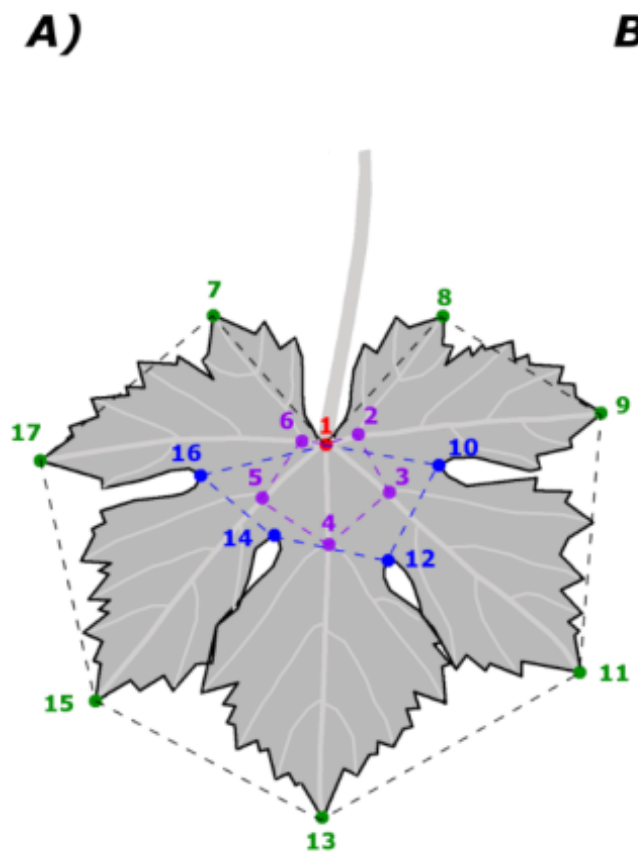

B),

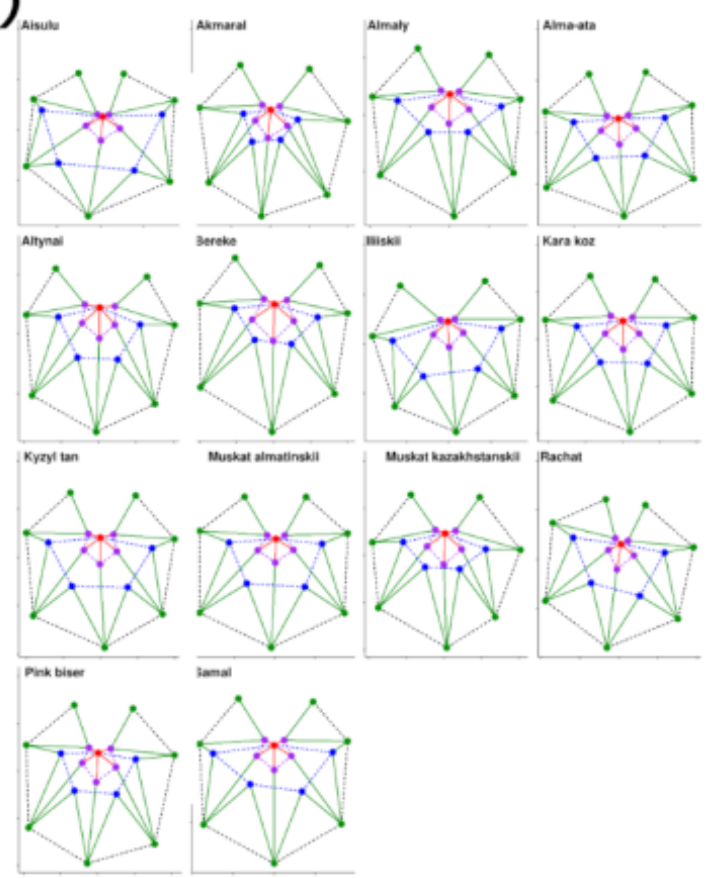

C)

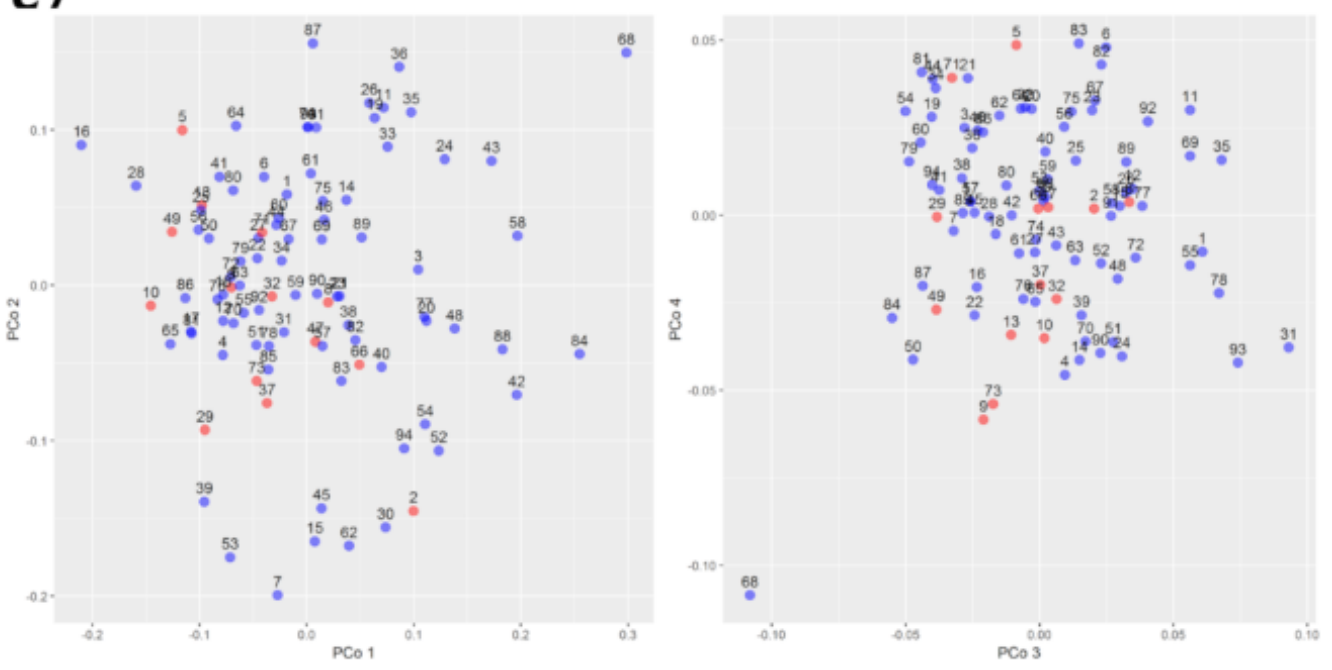

Figure 1. A: Landmarks of grapevine leaves used for Generalized Procrustes analysis (GPA). B: Mean configurations of 14 Kazakhstan grapevine cultivars obtained by GPA. C: Principal component analysis of Riemannian shape distances between cultivars. Kazakhstan cultivars are highlighted in red; numeration according to Table 1.

PCA was performed for each of these patterns and overall landmarks set with function "plotTangentSpace()" (Table 3; Figures 2 and Figure Supplementary 2 ). The first four principal components were sufficient to explain $98-99 \%$ of the variation of 
different patterns and nearly $98 \%$ for the full set of landmarks. Shape variation of each pattern is expressed in standard deviations of each principal component. The first two components of variation show a nonlinear relation. Pattern 3, describing leaf lobe tips, has the most impact on this variation and stronger nonlinearity than others. However, patterns 1 and 2 also show the relation. By summarizing the first two components of shape variation among the three patterns, the overall structure has an exceptionally strong nonlinear relation. These results may be evidence that grapevine leaf shape has too complex a nature, and optimization of more advanced approaches lay beyond the scope of the current study.
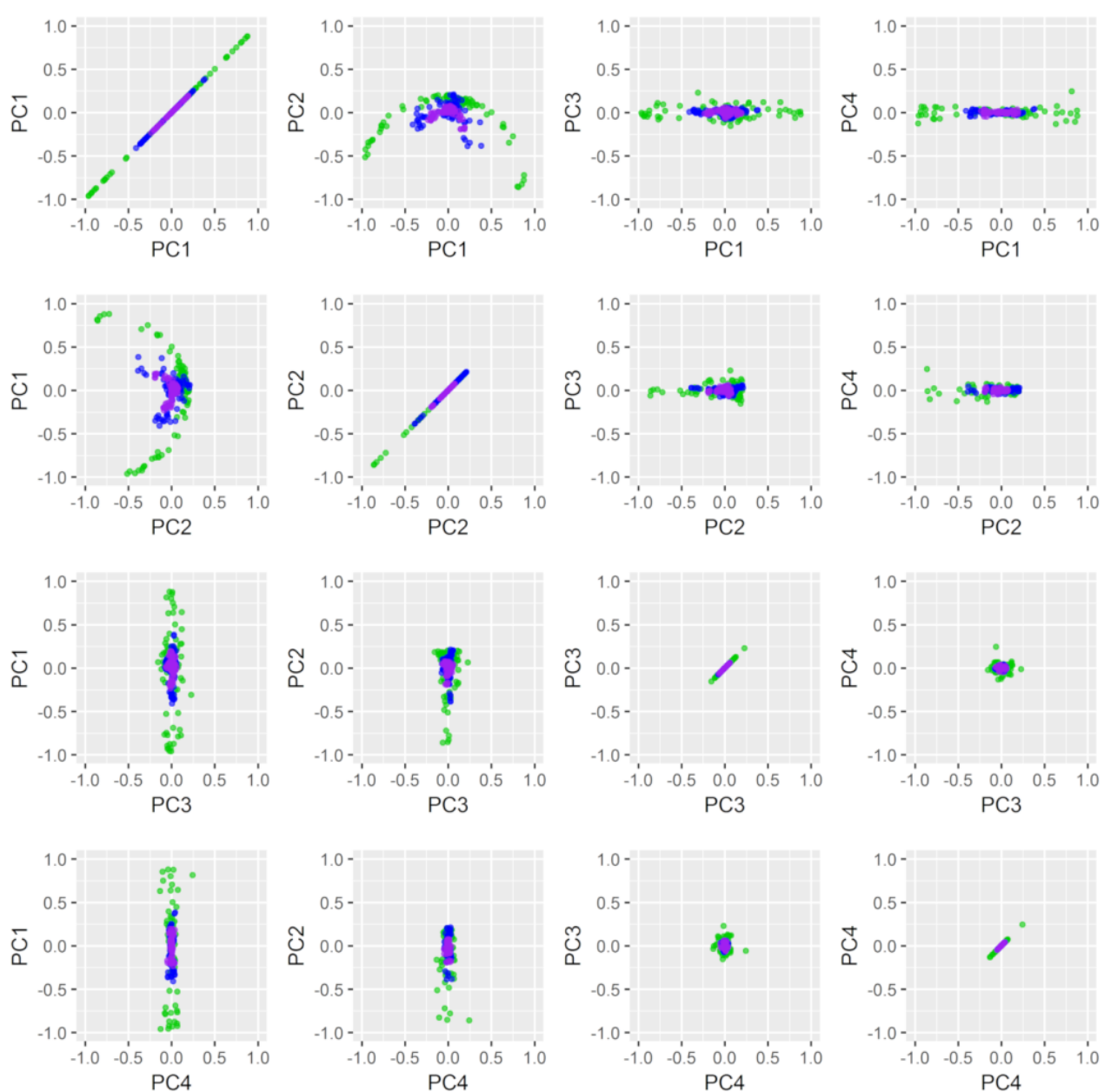

Figure 2. Plots of the first four principal components of variation for three leaf shape patterns among 94 cultivars (purple, blue, and green dots for patterns 1, 2, and 3, respectively). See also Figure Supplementary 2 for separate plots of patterns and summary of leaf shape variation. 
Table 3. Results of PCA of leaf shape variation among 94 grapevine cultivars.

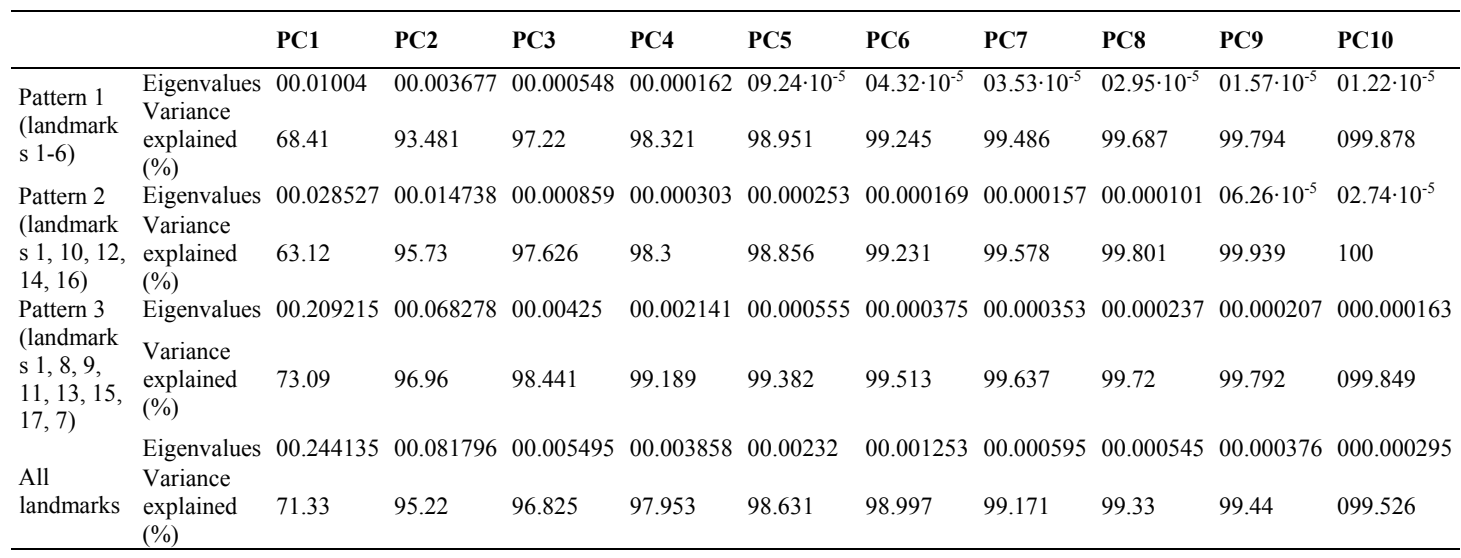

\section{Genotyping}

The microsatellite profiles of the accessions were compared with available representative profiles in the database http:/www.vivc.de/ (Table S2). Summary of SSR genotyping is available in Table S3. In our experiment, allele sizes were 2 nucleotides less for locus VVMD5(-2), 1 nucleotide less for locus VVMD27(-1), and 1 nucleotide more for VrZAG62 $(+1)$. In most data from various laboratories, allele size increments were 2 bp due to the nature of these markers, and 1-bp increment differences for VVMD27 and VrZAG62 were also identified (This et al., 2004). Such results are interpreted as a stutter or extra base additions by some Taq polymerases (Brownstein et al., 1996). In our study, six markers turned out to be sufficient to differentiate each of the cultivars. However, for a number of cultivars, there was no confirmation of identity with respect to pedigree either by bibliography or comparison with an international database, such as the Vitis International Variety Catalogue (VIVC); some confusion in field collection is assumed. On the other hand, for example, the pedigree of cultivar Muskat susanna (by breeder/bibliography Malingre S.P. $\times$ Muskat rozovii) was not confirmed when genotyping. In our study of marker profiles, one of the parents of Muskat susanna should be Madeleine angevine; the same is indicated in cultivar passport data in VIVC.

Kazakhstan cultivars and the same number of randomly selected European and Asian ones were compared to identify the features of allele representation (Table Supplementary 3). The total number of alleles was 77 , with 22 private alleles (56 and 3 alleles for Kazakhstan cultivars, 55 and 5 alleles for European cultivars, 66 and 13 alleles for Asian cultivars). In order to distinguish groups of cultivars in accordance with their genetic similarity, two methods based on different approaches were used: a UPGMA tree with Bruvo genetic distances (Bruvo et al., 2004) and Bayesian Monte Carlo Markov Chain simulation implemented in STRUCTURE (Pritchard et al., 2009). Configurations were tested with a number of clusters $(\mathrm{K})$ from 2 to 10 and combined results with the UPGMA tree (Figure 3). With $K=4$, distinct structure patterns corresponding to clusters on the 
UPGMA tree were observed. Three large groups were noted (Alma-Ata-Riesling; Altynay-Akhalili; Khindogny-Mushketnyi). In the first group, four cultivars (Alma-Ata, Rizamat, Kyzyl tan, Volgodon) were united in subclusters by Katta kurgan in their ancestry. The other 13 varieties belonged to the European cultivars. The second group united 12 cultivars of the eastern origin. In the third group, more than $1 / 4$ were eastern cultivars; $3 / 5$ cultivars were related in the pedigree due to Madeleine angevine or Csaba gyoengye (syn. Pearl of csaba). By VIVC, one of the Csaba gyoengye's parents was Madeleine angevine. Many of these cultivars have a second parent of some oriental variety. The fourth, smaller group (Sasun-Neiburger) was mixed.

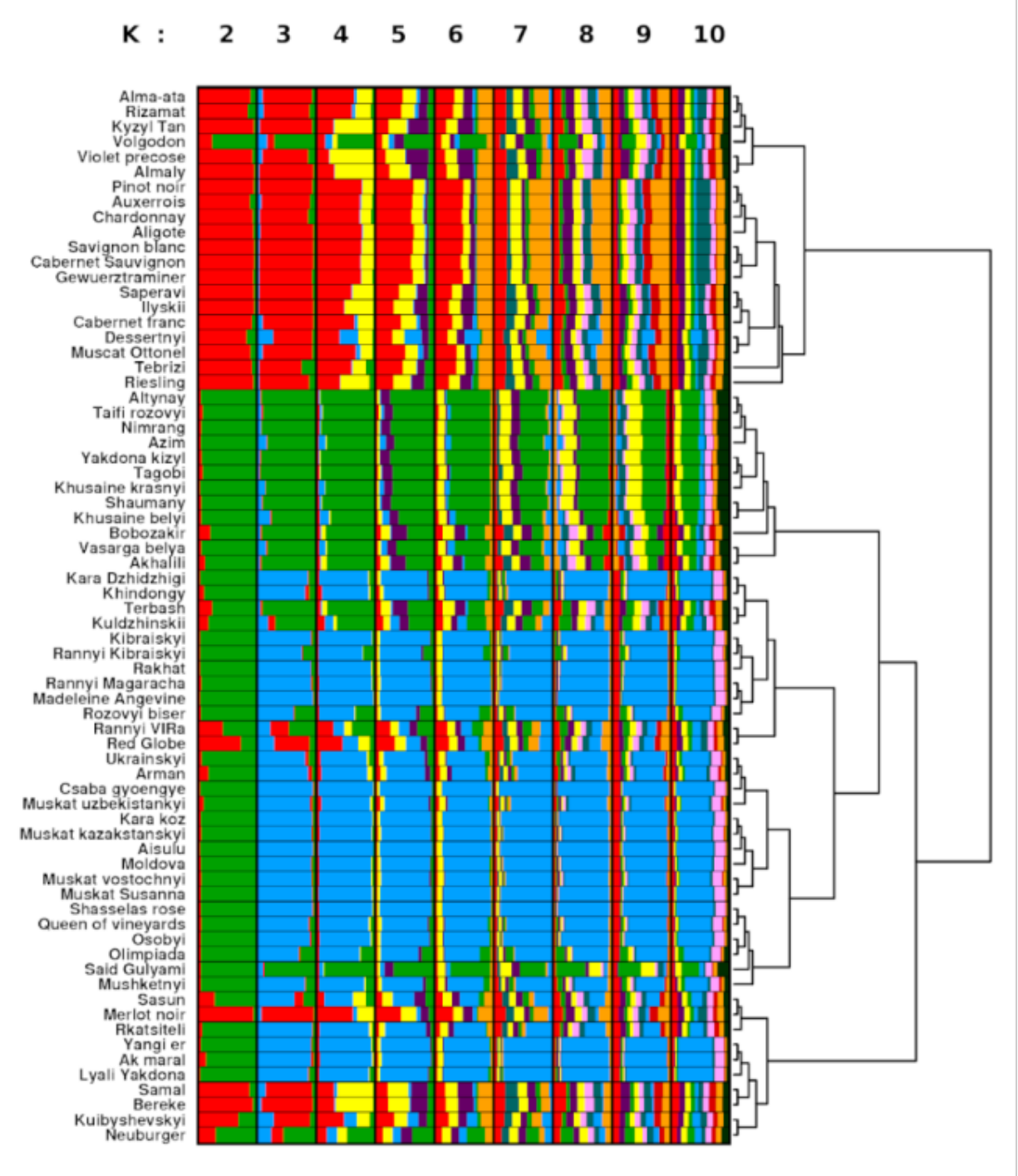

Figure 3. Results of Bayesian clustering of cultivars based on 6 SSR markers using the STRUCTURE software with the UPGMA tree of Bruvo genetic distances. 


\section{Identification of loci alleles related to oidium and mildew resistance}

In our research, molecular marker analysis revealed certain alleles related to pathogen resistance in several Kazakhstan cultivars (Table 4). In cultivar Bereke, declared highly field-resistant to oidium and mildew, there were 416- and 359-bp alleles of the Rpv10 locus associated with resistance to DM but none associated with PM resistance. Conversely, in cultivar Samal (Bereke's full sibling), declared fieldresistant to abovementioned pathogens, a 284-bp allele of the RUN1 locus was associated with PM resistance. In the VIVC, one of the Severnyi cultivar's parents is characterized as having resistance to DM/PM 8/1-leaf/bunch $(1=$ very low; $9=$ very high). Thus, Severnyi could be a source of resistance to DM in cultivar Bereke. Two resistance-associated alleles, 416 and $359 \mathrm{bp}$, of the Rpv10 locus were revealed in cultivar Almaly and its parent, Fioletovyi rannii. In these cultivars, the 284-bp allele of the RUN1 locus associated with PM resistance was shown as well. Breeders have characterized the Almaly cultivar as sufficiently resistant to both pathogens, whereas its parent based on bibliography (http://vinograd.info/), Fioletovyi rannii, is resistant to DM and sensitive to PM. In contrast, the VIVC degree of resistance to PM in Fioletovyi rannii is indicated as very high (9/9-leaf/bunch). Evidently, resistance to the pathogens in Kazakhstan cultivars Bereke, Samal, and Almaly is more likely due to inheritance from V. amurensis (Rpv10 locus). In view of Bereke and Samal cultivars' resistance to both pathogens, more research is needed following the development of new markers for new putative loci of resistance to each pathogen. Previously, resistance-associated alleles of the REN1 locus in wild and cultivated Central Asian grapes were based on four SSR markers (Riaz et al., 2013). However, two representatives (DVIT1803 and DVIT3351.27) from 40 accessions of V. vinifera subsp. sylvestris were identified as resistant by field test, wherein the former possessed four alleles and the latter had only two. Researchers speculate that alleles at other markers were lost due to recombination. In the other cases, the presence of the resistance-associated allele may be due to size homoplasy. Therefore, even in the presence of alleles of interest, marker analysis allows identification of accessions as potentially resistant that need to be verified in field screening. It should also be noted that hybrid family genetic analysis showed that resistance "is inherited dominantly, but degrees of resistance are defined by polygenic effects".

Resistance-associated alleles 283 bp of REN1 and 389 bp of Rpv3 were revealed in cultivar Alma-Ata and its parent Rizamat. The REN1 locus has Central Asian origin (Hoffmann et al., 2008). The presence of the resistance-associated allele of REN1 in Alma-Ata based on Asian cultivars is reasonable. Cultivar Muskat uzbekistanskyi has been described as weakly affected by oidium and possesses alleles of RUN1 (187 bp) and REN1 (283 bp). In Uzbekistanian Muscat, as well as in Rizamat and Katta-Kurgan, two REN1 alleles, 260 bp (VMCNg4e10.1) and 249 bp (sc47-18), were revealed (Riaz et al., 2013). However, testing of these cultivars for PM sensitivity was high (4-5), and none of these varieties have been ranked as resistant to oidium. Kazakhstan cultivar Aisulu is characterized by weak resistance to both pathogens and only possesses allele 214 bp of REN1, whereas its parent, Pearl of Csaba, "in the middle degree is affected by 
DM and sensitive to PM" as it possessed allele 389 bp of Rpv3 and 214 bp of REN1. Kazakhstan cultivars Kyzyl tan, Kara koz, and Muskat kazakhstankyi are sensitive to the pathogens and possessed only allele $214 \mathrm{bp}$ of REN1. In some $V$. vinifera cultivars analyzed, the presence of a resistance-associated allele of RUN1 in M. rotundifolia species was identified (Merdinoglu et al., 2003). It is worth noting that the cultivated grapevine $V$. vinifera has a cluster of resistance gene analog sequences (RGA) at the syntenous region on chromosome 12, closely related to MrRGAs at the MrRUN1/MrRPV1 locus in M. rotundifolia (Feechan et al., 2013). Phylogenetic analysis of coding regions at the syntenous locations have allowed researchers to suggest $V$. vinifera $T I R-N B-L R R$ genes at this locus share a common ancestor with the MrRGAs in M. rotundifolia (Feechan et al., 2013). Selection pressure took place in M. rotundifolia due to the presence of the pathogens.

Table 4. Results of amplification of markers associated with powerly mildew and downy mildew resistance loci in grape.

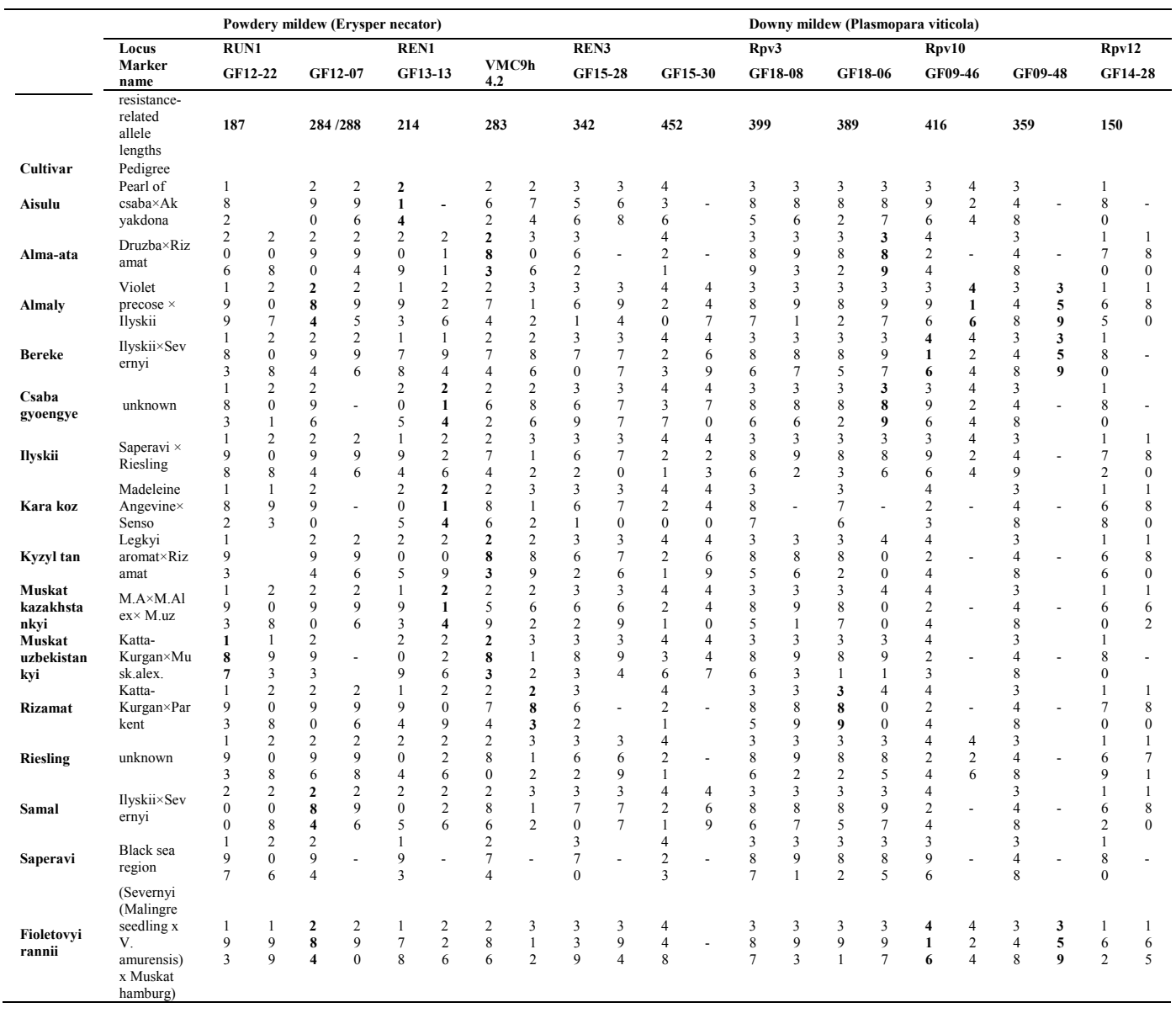


In our study, none of the cultivars tested with markers revealed alleles associated with REN3 or Rpv12 (from $V$. amurensis). Thus, in the absence of confirmation, the presence of $R p v 10$ or $R p v 12$ by marker- assisted selection in the developed grapevine hybrids with a high level of resistance suggests unknown resistance genes (Khafizova and Michlovský, 2016). For high-throughput markerassisted selection of disease-resistant grapevine cultivars, development of "perfect" genetic markers is the only guarantee. New strategies are yet to be developed to facilitate rapid evaluation of R-gene candidates (Feechan et al., 2013). This will help researchers to better understand the degree to which genes of interest are able to function in different genetic backgrounds (Qiu et al., 2015).

Results of SSR genotyping of collected grapevine cultivars herein show that local varieties in Kazakhstan retain their genetic proximity to their source breeding material. They do not form distinct groups and are distributed among European and Central Asian varieties according to their origin. This corresponds to admixture of cultivars used in the breeding process during the Soviet period. Thus, genetic properties of local cultivars derive directly from their predecessors. However, their interaction with specific environmental conditions of Kazakhstan may be of interest in further studies (e.g., in context of interplay of hybridized European and Asian genotypes or development of pure European varieties in continental climatic zones). Interaction between genetic and external factors in organism development results in its phenotypic properties, and morphometric (ampelometric) features of grapevine varieties cannot be ignored in such studies. Although the present study was not able to analyze associations between genetic and phenotyping data due to inconsistency of corresponding datasets and limited amounts of data, further development of this methodology may be important for both theoretical and applied aspects of grapevine biology.

\section{FUNDING}

This research was funded by the Ministry of Education and Science of Kazakhstan (Grant no. AP05132367).

\section{ACKNOWLEDGMENTS}

The authors thank Dr. Reinard Töpfer for the opportunity to do part of the research at the JKI Institute for Grapevine Breeding (Siebeldingen, Germany).

\section{CONFLICTS OF INTEREST}

The authors declare no conflict of interest.

\section{REFERENCES}

Adams D, Collyer M, Kaliontzopoulou A and Sherratt E (2017). Geomorph (3.0.5). Available at https://cran.rproject.org/package $=$ geomorph. 
Agurto M, Schlechter RO, Armijo G, Solano E, et al. (2017). RUN1 and REN1 pyramiding in grapevine (Vitis vinifera cv. Crimson seedless) displays an improved defense response leading to enhanced resistance to powdery mildew (Erysiphe necator). Front. Plant Sci. 8: 758. https://doi.org/10.3389/fpls.2017.00758.

Alba V, Bergamini C, Cardone M, Gasparro M, et al. (2014). Morphological variability in leaves and molecular characterization of novel table grape candidate cultivars (Vitis vinifera L.). Mol. Biotechnol. 56: 557-70. https://doi.org/10.1007/s12033-013-9729-6.

Alba V, Bergamini C, Genghi R, Gasparro M, et al. (2015). Ampelometric leaf trait and SSR loci selection for a multivariate statistical approach in V. vinifera L. biodiversity management. Mol. Biotechnol. 57: 709-719. https://doi.org/10.1007/s12033-015-9862-5.

Aradhya MK, Dangl GS, Prins BH, Boursiquot JM, et al. (2003). Genetic structure and differentiation in cultivated grape, Vitis vinifera L. Genet. Res. 81(3): 179-92. https://doi.org/10.1017/S0016672303006177.

Armijo G, Schlechter R, Agurto M, Muñoz D, et al. (2016). Grapevine Pathogenic Microorganisms: Understanding Infection Strategies and Host Response Scenarios. Front. Plant Sci. 7: 1-18. https://doi.org/10.3389/fpls.2016.00382.

Bacilieri R, Lacombe T, Le Cunff L, Di Vecchi-Staraz M, et al. (2013). Genetic structure in cultivated grapevines is linked to geography and human selection. BMC Plant Biol. 13: 1-14. https://doi.org/10.1186/1471-2229-13-25.

Barker CL, Donald T, Pauquet J, Ratnaparkhe MB, et al. (2005). Genetic and physical mapping of the grapevine powdery mildew resistance gene, Run1, using a bacterial artificial chromosome library. Theor. Appl. Genet. 111: 370-377. https://doi.org/10.1007/s00122-005-2030-8.

Bellin D, Peressotti E, Merdinoglu D, Wiedemann-Merdinoglu S, et al. (2009). Resistance to Plasmopara viticola in grapevine 'Bianca' is controlled by a major dominant gene causing localized necrosis at the infection site. Theor. Appl. Genet. 120: 163-176. https://doi.org/10.1007/s00122-009-1167-2.

Bodor P, Baranyai L, Ladanyi M, Balo B, et al. (2013). Stability of ampelometric characteristics of $V$. vinifera L. cv. 'Syrah' and 'Sauvignon blanc' leaves: impact of within-vineyard variability and pruning method/bud load. S. Afr. J. Enol. Vitic. 34(1): 129-137. https://doi.org/10.21548/34-1-1088.

Brownstein MJ, Carpten JD and Smith JR (1996). Modulation of non-templated addition by Taq polymerase: primer modifications that facilitated genotyping. Biotechniques. 20: 1004-1010. https://doi.org/10.2144/96206st01.

Bruvo R, Michiels NK, D'Souza TG and Schulenburg H (2004). A simple method for the calculation of microsatellite genotype distances irrespective of ploidy level. Mol. Ecol. 13(7): 2101-1206. https://doi.org/10.1111/j.1365294X.2004.02209.x.

Chitwood DH, Ranjan A, Martinez CC, Headland LR, et al. (2014). A modern ampelography: a genetic basis for leaf shape and venation patterning in grape. Plant Physiology. 164: 259-272. https://doi.org/10.1104/pp.113.229708.

Coleman C, Copetti D, Cipriani G, Hoffmann S, et al. (2009). The powdery mildew resistance gene REN1 co-segregates with an NBS-LRR gene cluster in two Central Asian grapevines. BMC Genet. 10: 89. https://doi.org/10.1186/14712156-10-89.

Doyle JJ and Doyle JL (1990). Isolation of plant DNA from fresh tissue. Focus. 12: 13-15.

Eibach R and Töpfer R (2003). Success in resistance breeding: 'Regent' and its steps into the market. Acta Hortic. 603: 687-691. https://doi.org/10.17660/ActaHortic.2003.603.95.

Emanuelli F, Lorenzi S, Grzeskowiak L, Catalano V, et al. (2013). Genetic diversity and population structure assessed by SSR and SNP markers in a large germplasm collection of grape. BMC Plant Biol. 13: 39. https://doi.org/10.1186/1471-2229-13-39.

Feechan A, Anderson C, Torregrosa L, Jermakow A, et al. (2013). Genetic dissection of a TIR-NB-LRR locus from the wild North American grapevine species Muscadinia rotundifolia identifies paralogous genes conferring resistance to major fungal and oomycete pathogens in cultivated grapevine. Plant J. 76: 661-674. https://doi.org/10.1111/tpj.12327.

Gessler C, Pertot I and Perazzolli M (2011). Plasmopara viticola: a review of knowledge on downy mildew of grapevine and effective disease management. Phytopathologia Mediterranea. $50 \quad$ (1): $3-44$ https://doi.org/10.14601/Phytopathol_Mediterr-9360.

Hoffmann S, Di Gaspero G, Kova L, Howard S, et al. (2008). Resistance to Erysiphe necator in the grapevine 'Kishmish vatkana' is controlled by a single locus through restriction of hyphal growth. Theor. Appl. Genet. 116: 427-438. https://doi.org/10.1007/s00122-007-0680-4.

Hvarleva TD, Russanov KE, Bakalova AT, Zhiponova MK, et al. (2009). Microsatellite linkage map based on F2 population from Bulgarian grapevine cultivar Storgozia. Biotechnol. Biotechnol. Equip. 23: 1126-1130. https://doi.org/10.1080/13102818.2009.10817626.

Khafizova A and Michlovský M (2016). New white resistant wine grape cultivars from hybrid family Rinot x Bv-7-6-2. Acta Universitatis Agric. Silvic. Mendel. Brunensis. 64 (5): 1569-1573. https://doi.org/10.11118/actaun201664051569.

Marrano A, Grzeskowiak L, Moreno Sanz P, Lorenzi S, et al. (2015). Genetic diversity and relationships in the grapevine germplasm collection from Central Asia. Vitis. 54: 233-237. 
Merdinoglu D, Wiedemann-Merdinoglu S, Coste P, Dumas V, et al. (2003). Genetic analysis of downy mildew resistance derived from Muscadinia rotundifolia. Acta Hortic. 603: 451-456. https://doi.org/10.17660/ActaHortic.2003.603.57.

Nurmuratuly T, Madenov ED, Nurtazina NY, Karycheva LA, et al. (2012). Genetic pool of local and aboriginal cultivars of apple, pear, apricot and grapevine in South and South-East Kazakhstan. Almaty.120 p. [In Russian; original title: Генофонд местных и стародавних сортов яблони, груши, абрикоса и винограда на юге и юго-востоке Казахстана].

Pokhriyal B, Thorat K, Limaye D, Joshi Y, et al. (2012) Microsatellite Markers-A Novel Tool in Molecular Genetics. Int. J. Res. Pharm. Chemi. 2: 397-412.

Pritchard JK, Wen X and Falush D (2009). Documentation for STRUCTURE software: version 2.3. USA: Department of Human Genetics, University of Chicago and Department of Statistics, University of Oxford. Available at https://www.ccg.unam.mx/ vinuesa/tlem09/docs/structure_doc.pdf.

Qiu W, Feechan A and Dry I (2015). Current understanding of grapevine defense mechanisms against the biotrophic fungus (Erysiphe necator), the causal agent of powdery mildew disease. Hortic. Res. 2(9): 15-20. https://doi.org/10.1038/hortres.2015.20.

Riaz S, Boursiquot JM, Dangl GS, Lacombe T, et al. (2013). Identification of mildew resistance in wild and cultivated Central Asian grape germplasm. BMC Plant Biol. 13: 149. https://doi.org/10.1186/1471-2229-13-149.

Rosenberg NA (2003). Distruct: a program for the graphical display of population structure. Molecular Ecology Notes. 4(1): 137-138. https://doi.org/10.1046/j.1471-8286.2003.00566.x.

Sack L and Scoffoni Ch (2013). Leaf venation: structure, function, development, evolution, ecology and applications in the past, present and future. New Phytol. 198: 983-1000. https://doi.org/10.1111/nph.12253.

Schwander F, Eibach R, Fechter I, Hausmann L, et al. (2011). Rpv10: a new locus from the Asian Vitis gene pool for pyramiding downy mildew resistance loci in grapevine. Theor Appl Genet. 124: 163-176. https://doi.org/10.1007/s00122-011-1695-4.

Sefc KM, Pejić I, Maletić E, Thomas MR, et al. (2009). Microsatellite markers for grapevine: Tools for cultivar identification \& Pedigree reconstruction. In: Grapevine Molecular Physiology \& Biotechnology, 2nd edn. Springer. Netherlands.

This P, Jung A, Boccacci P, Borrego J, et al. (2004). Development of a standard set of microsatellite reference alleles for identification of grape cultivars. Theor. Appl. Genet. 109: 1448-1458. https://doi.org/10.1007/s00122-004-1760-3.

Venuti S, Copetti D, Foria S, Falginella L, et al. (2013). Historical introgression of the downy mildew resistance gene Rpv12 from the Asian species Vitis amurensis into grapevine varieties. PloS one. 8(4): e61228. https://doi.org/10.1371/journal.pone.0061228.

Viscosi V and Cardini A (2011). Leaf Morphology, taxonomy and geometric morphometrics: a simplified protocol for beginners. PLoS one. 7(3): e0025630. https://doi.org/10.1371/journal.pone.0025630.

Welter LJ, Göktürk-Baydar N, Akkurt M, Maul E, et al. (2007). Genetic mapping and localization of quantitative trait loci affecting fungal disease resistance and leaf morphology in grapevine (Vitis vinifera L). Mol. Breeding. 20: 359374. https://doi.org/10.1007/s11032-007-9097-7.

Wickham H (2009). ggplot2: elegant graphics for data analysis. Springer-Verlag, New York.

Zhang J, Hausmann L, Eibach R, Welter LJ, et al. (2009). A framework map from grapevine V3125 (Vitis vinifera 'Schiava grossa' x 'Riesling') 9 rootstock cultivar 'Borner' (Vitis riparia x Vitis cinerea) to localize genetic determinants of phylloxera root resistance. Theor. Appl. Genet. 119: 1039-1051. https://doi.org/10.1007/s00122009-1107-1.

Zyprian E, Ochßner I, Schwander F, Šimon S, et al. (2016). Quantitative trait loci affecting pathogen resistance and ripening of grapevines. Mol. Genet. Genomics. 291(4): 1573-94. https://doi.org/10.1007/s00438-016-1200-5. 